\title{
Nineveh 1851: An Archaeography
}

\author{
Shawn Malley
}

Nothing could induce me to stay out here another year. I have been placed in every manner of inconvenience and annoyance and find myself again reduced to my own resources.

(A.H. Layard to Ambassador Stratford Canning, 12 August 1850)

\begin{abstract}
The present possessions of the Museum are in almost every room crowded together, and piled over each other like goods in a warehouse, and it is almost impossible to attempt correct classification, or satisfactory arrangement, which shall be instructive to visitors, or to isolate in any degree those objects to which it is desirable to direct particular attention. [. . .] As to arrangement and proper explanation of [the Assyrian sculptures], it is quite out of the question.
\end{abstract}

(Keeper of Antiquities Edward Hawkins, "Report to the Trustees of the British Museum", 3 July 1851)

\begin{abstract}
We always need to go beyond the object we have found, following it in becoming something else. It cannot be brought down to the results of empirical and analytic treatment. There is a necessary creative component in coming to know - being open to the other, receptivity, metaphor, the circumlocution, writing the genuine and generating object. Because meaning is ultimately unsayable, poetry is necessary.
\end{abstract}

(Michael Shanks, Experiencing the Past 135)

In the spring of 1851 the renowned 'discoverer of Nineveh' Austen Henry Layard abandoned his excavations in Mesopotamia for lack of resources, personnel support and clear directives from the British Museum. He returned to London in the summer to find the museum staff themselves desperately trying to sort through the cases of artefacts he had unearthed for them. ${ }^{1}$ Bulking large, they certainly provided no small measure of gratification to the Trustees, but little provision had been made for their arrival. Scattered and stockpiled throughout the building - on the front porch, in the main entrance and in a basement room accessed by a jury-rigged wooden staircase the material remains of Assyria stymied all sense of museal logic.(Jenkins 158-70) Edward Hawkins's directives to "classify," "isolate," "instruct" and "direct particular attention" were clearly secondary to the Trustees' desire to accumulate. In 1851, the museum was indeed forced to consider its purpose and identity as a warehouse, and its contents as goods.

By sardonically ascribing commercial value to the artefacts, Hawkins was certainly freighting the material remains of Assyria with the institutional authority of his office. But for a nation simultaneously celebrating its cultural, scientific and commercial ascendancy at Hyde Park, his joke demands that we consider the often contradictory ways the Victorian museum-going public came to value these trophies gathered from the distant outposts of British influence. The Great Exhibition itself begs certain questions about the rhetorical processes guiding the Victorian 
acculturation of Assyria into Britain. What were the implications of simultaneously collecting the Assyrian past and exhibiting Britain's imperial present and future? How did the tensions between the displays of progress and civilisation and the nationalistic, imperialist and commercial enterprises that sustain these cultural imperatives influence and reflect the reception and domestication of Assyria at mid-century?

While the British Museum is unquestionably the central authority in the archaeological project, Hawkins's concerns about proper display - the disparity between collection and classification - resonates in the circulation of Assyria outside of the hermeneutic controls of the British Museum. For in 1851 the nation was in the throes of Assyriamania. In this year John Murray released an abridged 'Popular' edition of Layard's best-selling Nineveh and Its Remains, dioramas of Nineveh opened at Thomas Burford's Leicester Square Panorama and at the Gothic Hall on Oxford Street, and the great city was the subject of many published poems, sermons, lectures and non-fiction works. ${ }^{2}$ If, as Hawkins avers, the British Museum sacrificed scholarship to commerce, the ideological attachments to Assyria were being rigorously debated in the competitive market of popular culture.

This article examines two groups of popular cultural documents composed during the Great Exhibition year. The first consists of a short expository piece published in Charles Dickens's magazine Household Words, entitled "The Nineveh Bull," and a poem by Walter Savage Landor, "To Layard." These works help expose the archaeo-imperial contexts of excavating, transporting and displaying prize Assyrian artefacts. The second group consists of three poems that bear the simple title "Nineveh," composed by Rugby student K. Blake, William Hunt of Corpus Christi College, Oxford, and Edward Henry Bickersteth, Curate of Banningham, Norfolk. While none of the Nineveh poets is particularly distinguished, their works are by virtue of the topicality of their subject and their engagement with the temporal and political problematics endemic of displaying antiquity and modernity in 1851 .

The apparently distinct realms of the material and the written - of exhibition and narration - have attracted in recent years the attention of theorists interested in tracking the transformations of artefacts in time and space. Poststructuralist literary theory and the linguistic turn in historiography have stimulated a growing awareness among archaeologists that material culture is not independent of, but intimately connected to, language: that archaeology "has to be written" (Tilley 11). Classical archaeologist Michael Shanks's portmanteau term "archaeography" (Homepage) is germane in this regard. Championing the semiotic coexistence of things, narratives, images and metaphors, archaeography encourages mutual respect between the creative and curatorial sensibilities needed for working with the material past, selfreflexivity about the ways and reasons why we create meaningful relationships with old things, and, moreover, democratisation of scientific discourse to include nonspecialist voices and audiences in the making of material culture from archaeological remains.

Shanks contends that an archaeological sensibility ("working on remains to translate, to turn them into something sensible - inventory, account, narrative, explanation, whatever") (Homepage) is indelibly embedded in the matrix of everyday life. He states in his "archaeological manifesto" that archaeography is deeply "committed to hybrid practice where art becomes scientific research, where the academy becomes an art studio, where pedagogy mingles with outreach into the community and industry, where practice can be research, where old disciplinary divisions give way to a committed address to matters of common human concern" (Homepage). In this way, archaeography invites us to consider the range of sensual 
experience that archaeologists too often take for granted: the desire to make the past speak, the sense of connection between place and past events, the drama and thrill of discovery, performances of the past and historical identity, discontinuities and continuities, entropy, and the contemporary mise en scène occupied by archaeologists, archaeographers, and artefacts alike.

Several ramifications emerge for the present article. If Shanks draws popular culture into the archaeological process, then the subjective experiences of the past in popular culture leave behind an important layer of archaeological experience. Archaeography allows us to trace archaeological sensibilities in time. The creative responses to Assyria in Victorian England are thereby part of the historical record they seek to document. What follows is a further 'archaeography,' a reading of the Victorians reading the artifactual world Layard exposed for them. Their poetic engagements help to see beyond the rather unhelpful catalogue numbers and provenance information that to this day greet the visitor to the British Museum, and to appreciate the social relationships that lay behind such classificatory schema: the tensions between the Victorian desire for possession and the pressures of mapping their historical identity across millennia. Through these literary encounters, we can see how the stones of Assyria appeared alongside the displays of the Great Exhibition as important signifiers of a British people simultaneously and assiduously claiming their inheritance and laying the foundations for their legacy.

Appearing in the February 1851 issue of Household Words, W. H. Stone's "The Nineveh Bull" is a minor yet highly imaginative contribution to the cultural reception of Assyria. The article is a short narrative that chronicles the life cycle of Layard's famous human-headed bull discovered in the northwest palace of the mound at Nimrud: from its carving to its installation in the palace of Ashurnasirpal II, from the fall of the city to its years of "slumber"(469) underground, and from its excavation to its restoration in London. Tidy and reductive, the story of discovery and domestication engages a wide range of ideological investments in the bull by employing prosopopeia, making the human-headed bull speak to and for Dickens's readers. But the success of the conceit - of a speaking human-headed bull - depends upon overcoming the central archaeological problem that artefacts are by their very nature inert, incommunicative things.

Shanks's portmanteau term "mute-ability" - of "mute stone speaking through the work of the archaeologist" (Homepage) - is certainly apropos. For the voice invests "metaphoric processes" into our relationships with artefacts. The animating voice resists the enervating processes of decay by reintegrating artefacts into the flow of time and forging meaningful patterns of ownership. For Dickens's readers, the bull literally speaks 'household words' through Stone: is rendered familiar and knowable through the poetics of historical discourse and desired historical identity.

The specific nature of the story is crucial for transforming the mute object into a communicative being. "The Nineveh Bull" is an originary tale that consolidates Britain's place in the march of civilisation through a reinvestment in the sacred soil of scripture; but such associations are created through disassociation of the artefact from the 'other' historical experiences of the people who occupy the territory in the expanse of time between the fall of the city and its 'discovery' by Layard. The bull's memory is decidedly European. As if awakened from a dream, the bull remembers its native country being visited by the Persian king Cyrus, the Athenian historian Xenophon and Alexander the Great, brief punctuations of civilised interest in a geographical region traversed by Arabs: "at times a dark figure flitted by, cursing me as the unbelievers' idol." Stone transfers ownership and intelligibility to Layard, who 
appears as a "lord among them." Salvaged from their ignorance, the bull "rejoiced in spirit, for I saw he knew me and knew my history; I was again awake and restored to the world" (469). In the absence of contextual archaeological data, the bull's identity is fully cast in the truth of scripture and the revelation of racial and cultural superiority that the biblical narrative re-enforces.

But what can the artefact actually say about the present that is not buried in the kind of past it is made to testify to? This problem is deeply embedded in the ways Western archaeologists have framed their narratives. Rosemary Joyce observes that "archaeology has exploited two chronotopes extensively. One of these is evolution (or progress), the other discovery (or experience)" (34). In "the chronotope of discovery, the writer is positioned inside, even at the centre, of things. Like progress, discovery is ideological." In Stone's narrative, the artefact confronts Arab incredulousness and hostility, thereby standing in for the absent archaeologist. "Actions over time are," states Joyce, "subordinated to the timeless moment, a moment in which the significance of things is pinned down" (35). The romance of discovery is crucial for asserting the need for dispossession and for what Johannes Fabian calls "the denial of coevalness" that typifies the colonial and anthropological discourse employed by Stone (31).

In excavation acts, rarity is also established for the object through a dialectical rhetoric of loss and recovery. The acquisition of Assyria begins at the moment of disassociation of local communities from objects; the Arabs shoulder the burden of loss - what is intellectually lost on them can be taken away - so the experience of discovery is important for getting time moving again, for establishing the chronotope of progress and the imperialist paradigm of Western inheritance. As museologist Eilean Hooper-Greenhill observes, "meanings may change radically as the object is moved from one site of semiosis to another. As the moves take place in time, and across space, earlier meanings may be lost or recovered, overlaid by new significations, or reinterpreted by different interpreters" (153). Stone's story thus kick-starts the narrative of movement from its original physical and interpretive ground by employing forces upon the object, even if, in this instance, they are 'primitive.' But primitivism is itself a modern production and a way of seeing the object in relation to the activities around it. As 'living ancestors' (albeit degenerate), the Arabs are important for establishing continuity with the past and for locating the artefact's authority as old and otherly; yet they are themselves cleared away like the shifting sands as the monuments are brought within the scope of British heritage. The narrative of relocation requires the translative action of contemporary forms of scientific knowledge draped in pleasing images of the antique aura of the East. The artefact is thus legitimated as an artefact within the poetics of dislocation.

The sensual logic of speaking and hearing is clearly a means of embodying the social experience of modernity in relation to the past. Like the Crystal Palace, the story is deeply committed to the imperialist project of gathering and displaying the products of the world. But it also documents certain cultural anxieties about the very modernity it ostensibly celebrates. While Stone's bull pays lip-service to the terrible lessons of empires - it exhorts its new custodians, "boast not, ye vain-glorious creatures of an hour. I have outlived many mighty kingdoms, perchance I may be destined to survive one more" (469) - the bull remains confident in its bondage, caged in, as Frederick Bohrer puts it, "a narrative of captivity" (174). The bull's very entropic history and warning are secondary to the narrative of enslavement itself, indeed to the powers of narrative enslavement. Simon Knell reminds us that "objects are 'made to speak,' [. . .] but in this 'conversation,' is the object active or passive? Does it embody and communicate some aspect of ourselves or is it simply a slave to 
our words and thoughts?" (7). Stone shies away from the disturbing implications of Assyria that he rather programmatically raises for those with the power to mobilise expeditionary teams and naval and commercial vessels, as well as the geopolitical and imperialist investments that these scientific activities depended upon and supported.

Walter Savage Landor's poem "To Layard" probes more deeply into the troubling ideological territory opened by Stone. His 36 verse line encomium to the archaeologist considers the ways ownership is caught up in sensitive issues of representing the archaeological reality of decay, ruin and entropy. Like "The Nineveh Bull," the poem tries to cement past and present in a continuum, but for Landor this impulse functions as a sign of loss. The cultural imperative to forge solidarity with the past in an age committed to the progress of technology and commerce engenders solipsistic confusion. By negotiating the passage of time and space from antiquity, Landor's poem raises the sneaking suspicion that England is being held ransom by its own history.

The poem is at first glance a lament for a world that can no longer value heroic deeds nor impart upon the poet the power to immortalise heroes. The present age is defined, rather, by the absence of poetry, though not individual acts of heroism. In this case, Landor reads the conditions of Layard's early return to England and abortive expedition as the mark of an age that can produce but not properly appreciate Layard's national sacrifice:

No harps, no choral voices, may enforce,

The words I utter. Thebes and Elis heard

Those harps, those voices, whence high men rose higher;

And nations crowned the singer who crowned them.

His days are over. Better men than his

Live among us: and must they live unsung

Because deaf ears flap round them? Or because

Gold lies along the shallows of the world,

And vile hands gather it? (1-9)

While the issue of Layard's fame is by 1851 clearly misplaced, ${ }^{3}$ the range of interests drawn into the poem is symptomatic of the deep tensions underscoring the archaeological project itself. While the poem celebrates Layard as discoverer of Nineveh - "who raisest cities from the dust, [. . .] And rescuest thrones and nations, fanes and gods, / From conquering Time" (13, 16-17) - the ways of knowing Assyria are deeply embedded in the conditions of modernity, which the poet characterises as vain, corrupt and bureaucratic. The poem is divided against itself, on the one hand invoking Layard's name in an old-fashioned encomium and, on the other, indicting a deaf-eared, gold-digging age bereft of poetic sensibility.

The poem at this point retreats to a meditation of waste itself, to the inevitable conclusion that archaeology is the science of entropy:

Cyrus raised

His head on ruins; he of Macedon

Crumbled them, with their dreamer, into dust:

God gave thee power above them, far above;

Power to raise up those whom they overthrew,

Power to show mortals that the kings they serve

Swallow each other, like the shapeless forms, 
And unsubstantial, which pursue pursued

In every drop of water, and devour

Devoured, perpetual round the crystal globe. (27-36)

The poem comes full circle, for the archaeologist is ironically the prophet of corrupt modernity. The "crystal globe" - i.e. a solar microscope, a kind of magic lantern that enables the projection of microscopic images onto a screen - is a scientific instrument that both contains and projects the microbial lessons of entropy, of power destroying power. The entropic lessons Layard draws from the ruins of Assyria are actively at work in the microscopic concerns of the present. For Stone, entropy is neutralised through voice, but for Landor, the terrible lessons of history in a scientific age are decidedly and irrevocably ocular and exhibitionary.

The three "Nineveh" poems of 1851 conflate Landor's underlying criticism of a modern world divided against itself and the imperialist domain of British acculturation playing out in Stone's narrative. Collectively, they offer a fairly orthodox picture of contemporary Mesopotamia as a modern wasteland and tangible sign of God's wrath. The poems amplify the British ability to read the landscape, uncover its treasure, and draw appropriate conclusions that at once validate the archaeological operation as a worthwhile colonial enterprise and as a warning against imperial hubris based on the biblical stories of Nineveh in the books of Jonah (God's mercy) and Nahum (God's wrath). While the archaeological tension between decay and resurrection is neatly resolved through deference to Scriptural interpretation, each poem nonetheless engages the ontological horrors of archaeological indeterminacy that we find in Landor's cool, scientific image of cellular destruction. Their archaeological 'poetics' is firmly, if unconsciously, based in archaeology as a science of decay. Each mediates and orders entropy by locating it as an active process at work in the past and in the degenerate present of the East. But decoding these fragments within the Christian worldview under which colonialism and Western civilisation spread unquestionably threatened the pretences of a stable political and moral world that collecting artefacts attempted to reify.

Blake's "Nineveh" is arguably the most straightforward of the three poems. Its 260 blank verse tour de force of the city's rise and fall begins conventionally with an evocation and documentation of "great Nineveh" at its height. Blake invites the reader to contemplate the sensuous delights of the city, to imagine how the:

gay terraces,

[And] hanging gardens, radiant with bloom,

Filled all the wind, the dreamy loitering wind,

With delicate odours, till the very air

Reeled in the vapours of the dim noon-tide,

A tremulous fragrance, interfusing all.

And all the broadway of her wondrous walls

Resounded to the tramp of mailed feet,

As ceaselessly beneath the burning sun

Her sentinels kept watch; below the while

Flowed through her streets the stream and hum of men;

And gazing upward at the giant works,

Or lost in wonder [. . .]. (41-53) 
The sense of wonder and enchantment is firmly Orientalist. But this introduces a troubling paradox of the East in the Victorian imaginary: its attractiveness is a sign of its demise. Exoticism is always on the brink of collapse:

Like ripe fruit shaken from autumn boughs,

Such was great Nineveh; her outstretched arms

Vexed the nations, as she fought and won,

Doing blind service; knowing not the while

That death was treading on the heels of sin.

[...] O what words,

What winged, armed, words, can weave a tale

Of sadder moral, or breathe more of death!

Of utterest death, and blank oblivion! (72-76; 83-86)

For Blake, the term oblivion conveys the dual sense of destruction and ignorance ('oblivious'). In the immediate context of the historical fall of the city to the Medean army in $606 \mathrm{BCE}$, the city's ignorance is an affront to a vengeful God. But ignorance needs a modern analogue to connect the biblico-archaeological landscape to European interest. Assyrian ignorance in antiquity bypasses the European reader and settles once again on the Arab. The site is now occupied by "the thoughtless Arab's tent, / The wandering wild Arab's shifting home" (90-91). As in Stone, Arabs bear the modern burden of archaeological indeterminacy that the European can experience and enjoy, but ultimately overcome:

Little thought Nimrod that that realm should shrink

And shiver into nothing, and be lost;

And that his children in the after-time

Should lightly tread upon the entombed ruin,

And raise bare huts o'er sunken palaces,

Unwitting of the splendour underneath;

Till that a stranger, magically wise,

Should come and disinter the ancient wonders,

And lay his finger on forgotten things,

Troubling the surface of the wind-laid plain

With mystic trench; and from some broken stone

Or column should divine and re-create

Temples, streets, palaces, and terraced walls. . .

The grand dead past that shames their present down. (99-116)

The poem folds back onto itself, validating through 'mystic trenches' the original evocation of gay terraces and hanging gardens of the corrupt city in its prime. In British hands, archaeology and poetry conspire to raise and raze the city perpetually. Yet the formation of historical and scientific knowledge is always subject to interrogation. As Frederick Bohrer observes, "the relations of difference through which the exotic is communicated are not bi-directional, but hierarchically structured" (16). In this way Blake eludes archaeology's central problem of decay by feeding it into a moralistic reading of Nineveh's destruction: that it was destroyed as a sign of God's blessing on England, its "splendour" preserved for the "magic" of its agents to disinter and transplant as signs of prosperity and communion with the divine. The 
poetics of remembrance are wrapped up in the religious sensibilities of its readers; the poetics of exoticism, in the spatial orientation of England as global leaders.

Such easy and self-satisfied extrapolations, to borrow from Lander's image of the solar microscope, tend to project what they magnify. If England is the screen for Nineveh's resurrection, it cannot easily escape self-identification with, in Blake's words, the "grand dead past that shames their present down" (116). While the poem conventionally resolves with a meditation on time and a reminder to be good and God-fearing, the energy of discovery and recreation inescapably confirms the unyielding force of entropy in the world. As in Landor and Stone, the British themselves are agents of entropy, for knowledge of Assyrian splendour pulled out of the ground and shipped 'home' to England has made the country older as well as wiser. The imagined relationship between God and humanity that Blake grafts onto the excavations is inevitably haunted by absence, is a projection of desire for immortality and a need to escape or rewrite or evade a similar fate by conflating archaeological knowledge with Christian piety. The poem ends with a question that attempts to close this hermeneutic circle:

'[...] the glad earth

Shall clap her hands and burst in singing forth

Over thy ruin; and the sun shall rise

And see no comforter, no mourner there.' -

So spake the prophet [Nahum] centuries ago:

Is not his prophecy a history now? (190-95)

But with the arrival of the "magically wise" Layard, the prophecy demands material proof. The God of the poem is merely a god of archaeology speaking through broken pieces retrofitted by historical discourse; the remains of Nineveh must be safeguarded poetically within and as Scriptural discourse. The evolutionary thrust of Blake's archaeology inadvertently opens up a hybrid position wherein the artefacts resist the discourses that seek to render them intelligible.

Alfred Hunt's "Nineveh" - a poem of nearly 200 heroic couplets - follows a similar trajectory of evocation of the lost world, the fall configured through contemporary Arab ignorance and degeneration, and meditation on the lessons for England. Assuming a bardic persona, the speaker evokes the enchantments of the past and the mordant pleasures of contemplating present waste. For Hunt, Nineveh is England's latest 'City of the Dead': "Tis but a shapeless mass, yet something there / Tells a wild tale of ruin and despair" (11-12). Of the three poems, Hunt's "Nineveh" is the most sumptuous in its evocation of Nineveh. The poem has a museum-like quality, an inventory of extinct life. The speaker-cum-cicerone is the genius loci of the ruins:

The spirit of eld is on me, as I stand

On Zagros' brow, three thousand years expand

Their mythic glories, and the days appear

When all was life - all joy - all beauty here.

Oh gorgeous vision! when this sunlit plain

Rippled in golden seas of ripening grain:

When the far-ranging eye enraptured, traced

One citied wilderness, one people waste:

One maze of spire, and pinnacle and shrine 
Sparkling along the dimmed horizon's line.

Temples were there, on piled-up mountains raised,

Whose eaves with gold, whose walls with vermeil blazed:

With aisles on aisles in lustrous long array ... (75-87)

The speaker continues in a similar vein for several pages. What is interesting is not so much what Hunt says about the city as the nature and circumstances of his poetic resurrection. Hunt's golden age of course never existed, and his imaginative reconstruction is only slightly encumbered with material Assyria. His postarchaeological Nineveh is an Orientalised Xanadu poised on the distant margins of British faith and, moreover, British markets. The poem's antiquarian positioning is important for connecting the lost world to contemporary concerns:

And flowing round two sides, a lordly tide

Reflected silken-sailed flottillas' pride.

And quays beheld with richest hand unrolled

The wealth of Ind, and Ophir's ruddy gold.

Earth's tribute-offerings, over land and sea,

Bright Queen of Cities, found their way to thee!

For thee the 'Desert-ship' high-laden came

Through moving sands, and reddening spires of flame,

Bearing rare gems, and pearls and corals gay

And bales of rustling silks from far Cathay,

To deck they crimson-clothed bazaars, and feed

Wealth's pampered pride and languid luxury's need. (101-12)

The underlying irony is that Nineveh's wealth, which is the cause of its decadence and downfall, is the very reason why England is so attracted to the East. The reference to the ships, quays, tide and Queens are self identifying markers of England's own empire and wealth. India lingers on the margins of the poem. The land is haunted by Alexander, the "youthful conqueror, speeding on / To grasp the gorgeous Orient's dazzling crown" (198-99). Layard, the "bright-eyed stranger [. . .] from Frangistan / Master of mightiest spells," picks it up (210-11). The "Spirit of eld" sounds suspiciously like the 'Spirit of commerce'.

While the poem retreats to the conventional 'Lest we Forget' motif as a way to rescue its readers from too close an identification with the horrors of Eastern effeminacy ("languid luxury") (192) and entropy ("Tis but the sport of time hath flashed the light / Of our world's noonday on millennial night") (229-30), the burden of remembrance for the modern reader lies heavy upon the poem nonetheless. The Assyrian threat cannot be so easily contained within the biblical narrative, and the poem certainly promotes identification with the imperial history it tries to circumvent. For the speaker ultimately confronts emptiness:

Where now those nations? though the sunbeam shines

Once more through palace courts or temple shrines,

Where once in sacred calm, or restless strife,

Throbbed the full pulses of their mighty life.

They rise not now! those senseless gods alone

Survive, to frown in everlasting stone

Relics of awful memory! since your day 
Time's whirling wheels might almost own decay! (274-81)

The collection of artefacts - and their poetic arrangement - offers a formidable bulwark against Eastern entropy, pride and decadence; but the paradox remains and the magic of archaeology conferred upon Layard casts its own spell: the flattering discourses of God, Queen and Country that attract the British gaze to the city are mirrors of England's own imperial hubris.

Of the three Nineveh poems, Edward Bickersteth's is arguably the most complex engagement with the poetics of ruination. It is the longest - 35 Spencerian stanzas framing a narrative section of heroic couplets - and the most mordant. Like Blake and Hunt, Bickersteth treats Nineveh as a sign of entropy and moral degeneration, but unlike them, the archaeological materials do not lend themselves to revival, to a temptation to parade Nineveh before the reader. In this sense, the poem is the most honest engagement with artefacts: they are ultimately things cut off in time. The tone is elegiac, but there is no longing for this lost world, no desire nor need to marvel at its bygone glories. And this is precisely the ideological message for the curate. Nineveh was not built to last. It stands unequivocally as a sign to "man [of] the eternal truth of God!" (468). The poet speaker asks "Who shall repaint her vanished scenes of glory, / Or weave her shattered woof of fragmentary story? (98-99)." The conventional answer is the poet. But the speaker likewise resists this urge. For the poem is a vast encomium to destruction itself ("Woe to the land of Assur!" is repeated five times in the opening five stanzas). The speaker invites the reader to consider how "Gloom settles on those silent wastes of snow; / The colours fade like dreams, and all is wan, / Save intermittent starlight, dimly glimmering on" (106-108). The speaker conflates prophecy with archaeological processes of decay, entropy and waste:

Time digged thy grave, and heaped the dust on thee

Soon died the echo of the dying groan;

And travellers, who came thy wreck to see,

Asked, and received no answer - Where is Nineveh? (454-57)

The concluding stanzas offer archaeological proof of the divine presence guiding evolutionary time, but where Blake and Hunt confidently raise Nineveh in order to destroy it and draw the appropriate lesson of being faithful servants of God, Bickersteth's Nineveh is firmly and confidently buried.

In this regard Bickersteth resists the temptation to imagine self in these ruins. The temporal trajectory for England lies, rather, in the future. Contemplating "the evening of the world," (458) the speaker translates biblical archaeological into the millennial promise held out to the Christian faithful. Archaeology is entirely compatible with Scriptural narratives of the end, rather than the beginning:

Men throng all paths of knowledge; Science dives

Below the ocean's bed, the mountain's base,

And from the bowels of creation rives

The monumental stones which dimly trace

Earth's primal story - then she soars apace

Above our little orb, and speeds afar

Mid distant planets her unwearied chase,

Skirting their track as in a seraph's car

From luminous world to world, from gorgeous star to star. (476-84) 
Similar to Landor's image of the solar microscope, the archaeological lessons are projected outward. The very cosmos mirrors earthly activity. In the penultimate stanza the speaker asks: "Who shall recall to life the things that were? / Or wake the spectral forms of thy vast sepulchre?" (519-20). The answer, like Landor's, is in the form of negation:

No, while the ages of the shattered world Roll slowly to the final term of time,

There shalt thou lie in desolation, hurled By vengeance from that pinnacle sublime

Whereon thou satest in thy glory's prime (521-25)

Unlike Blake and Hunt there is no pleasure in contemplating archaeological time and ruination. Enveloped in the scientific drive to chart progress in time, space and knowledge, archaeology is an active means of shaping and mapping the future. While all three Nineveh poets arrive at the same conclusion - that the stones of Assyria reveal the divine hand at work in earthly affairs - Bickersteth uncompromisingly locates England's own end in the archaeological poetics of waste.

In this essay I have been arguing that the literary engagements with archaeology and ruination inspired by Layard's excavations help us appreciate the flexibility and complexity of Nineveh at mid-century as a spatial and temporal signifier of a desired national identity, as well as the cultural anxieties of identification through the backward-looking science of archaeology. Nineveh was a means of looking both outward and inward. In Hunt and Blake, the archaeological poetics of entropy respond to a desire to venture out, to reclaim imaginatively a distant spiritual homeland. As a sign of British agency in Mesopotamia, archaeology resonates in the larger imperial context of the Eastern Question itself. Claiming archaeological territory was an important diplomatic and rhetorical exercise for a Christian nation committed to protecting its commercial interests in, and religious connections to, the Ottoman East. The power to excavate stones and to shape them into meaningful narratives is undoubtedly an expression of the political power to reinvest the dead world with the living presence of God and God's people, who have returned to the cradle of civilisation to protect its history and shepherd it into a new age of Western, global modernity.

In Bickersteth, Stone and Landor, on the other hand, entropic discourse describes a society whose global vision was turned intensely inward and homeward on itself at Hyde Park. The contemporary imagery enveloping the Crystal Palace - the beacon of technological progress and moral and social harmony - illuminates the Victorian project of raising Nineveh. Assyrian archaeology and the poetic encounters with the biblical landscape it inspired can not make much sense outside of the cultural discourses of material and commercial progress on display at the Great Exhibition. If Nineveh seemed to be rediscovered by divine authority - as a reinvestment of God back into history and into the material conditions of modernity - its reappearance is also the product of a desire to collect and exhibit, to stockpile "the past in plain view," because we need, in the words of Jean Baudrillard, "a visible past, a visible continuum, a visible myth of origin to reassure us as to our ends" (76). But like the disastrous war in the Crimea that was to shake Victorian society to its very core, such archaeological and imperial investments are always haunted by the ghost of the past, the shadow of entropy that has historically fallen over great empires. Archaeology as 
the science of entropy inevitably haunts the objects and the narratives of return that they are conscripted into.

Archaeologists and archaeographers like Michael Shanks maintain that our semiotic engagements with material remains are fuelled by the desire to document social identity. The literary reflections on Assyria in 1851 leave behind an impression for us to follow, of the imagined relations between the self and the self that was, a self that was also located in the temporal and spatial differentiation from others and firmly located in the rhetoric of Victorian modernity, commerce and colonialism. This 'archaeography' of Nineveh in 1851 has endeavoured to show that the cultural responses to Layard's excavations is also an archaeography of the cultural desires that can in part explain the Victorians' need to exhibit themselves to the world. 


\section{Notes}

1. He conducted two expeditions from 1845 to 1847 and 1849 to 1851 . For details of Layard's departure from Mesopotamia refer to Larsen, 286-90. Other narrative histories of Layard's excavations include Fagan and Waterfield.

2. The long list of 1851 publications includes Walpole, Vaux, Fergusson, Layard as well as a number of anonymous texts. For a study of the aesthetic reception of Assyria in Europe, see Bohrer.

3. By 1851 the best selling author of Nineveh and Its Remains (1849) was a household name. He would go on to translate his archaeological fame into a long and distinguished career in politics and diplomacy.

4. For a survey of the City of the Dead motif in English literature see Wallace. 


\section{Works Cited}

Baudrillard, Jean. The Illusion of the End. Trans. Chris Turner. Stanford, CA: Stanford UP, 1993.

Bickersteth, Edward Henry. Nineveh, a Poem. London: Wertheim and Macintosh, 1851.

Bohrer, Frederick N. Orientalism and Visual Culture: Imagining Mesopotamia in Nineteenth-Century Europe. Cambridge: Cambridge UP, 2003.

Hawkins, Edward. "Report to the Trustees of the British Museum, 3 July 1851." Return to an Order of the Honourable The House of Commons, dated 22 June 1852, for 'A Copy all Communications made by the Architect and Officers of the British Museum to the Trustees, respecting the Enlargement of the Building of that Institution.... .' British Parliamentary Papers vol. 28, 1852. Folio 557.

Fabian, Johannes. Time and the Other: How Anthropology Makes Its Object. New York: Columbia UP, 1983.

Fagan, Brian M. Return to Babylon: Travelers, Archaeologists, and Monuments in Mesopotamia. Boulder, CO: U of Colorado P, 2007.

Fergusson, James. The Palaces of Nineveh and Persepolis Restored. London: Murray, 1851.

Hooper-Greenhill, Eilean. Museums and the Interpretation of Visual Culture. New York: Routledge, 2000.

Hunt, Alfred. Nineveh A [Newdigate] Prize Poem Recited in the Theatre, Oxford, July 3, 1851.Oxford: Chiswick 1851.

Jenkins, Ian. Archaeologists and Aesthetes in the Sculpture Galleries of the British Museum 1800-1939. London: British Museum, 1992.

Joyce, Rosemary A. The Languages of Archaeology. New York: Blackwell, 2002.

Jex Blake, Thomas William. Nineveh, a Prize Poem. Rugby: Crossley and Billington, 1851.

Knell, Simon J. "Museums, Reality and the Material World." Museums in the Material World. Ed. Simon J. Knell. Abingdon: Routledge, 2007. 1-28.

Landor, Walter Savage. "To Layard,” International Monthly 3.1 (1851): 98.

Larsen, Mogens Trolle. The Conquest of Assyria: Excavations in an Antique Land, 1840-1860. New York: Routledge, 1996.

Layard, Austen Henry. Popular Account of Discoveries at Nineveh. London: Murray, 1851.

---. Letter to Ambassador Stratford Canning. 12 August 1850. MS. Additional Manuscripts 38942 Folio 43. British Museum, London.

Nineveh and the Tigris. London: np., 1851.

Nineveh, the buried city of the East. London: National Illustrated Library, 1851.

Sandys Wright Vaux, William. Nineveh and Persepolis: An Historical Sketch of Ancient Assyria and Persia. London: np., 1851.

Shanks, Michael. Experiencing the Past. Routledge: London, 1992.

---. Homepage. Michael Shanks: Archaeologist at Stanford, n.d. Web. 18 July 2012.

Stone, W. H. "The Nineveh Bull," Household Words 8 Feb. 1851: 568-69.

Tilley, Christopher. Interpretative Archaeology. Oxford: Berg, 1993.

Wallace, Jennifer. Digging the Dirt: The Archaeological Imagination. London: Duckworth, 2004.

Walpole, Frederick. The Ansayrii, and the Assassins; with Travels in the further East, in 1850, 51; Including a Visit to Nineveh. London: Bentley, 1851. 
Waterfield, Gordon. Layard of Nineveh. London: Murray, 1963. 